DOI https://doi.org/10.15407/csc.2021.05-06.088

UDC 004.75+004.932.2:616

O.S. KOVALENKO, DSc. (Medicine), Professor, Head of the Medical Information Systems Department, International Research and Training Center for Technologies and Systems of the NAS and MES of Ukraine, Glushkov ave., 40, Kyiv, 03187, Ukraine, askov49@gmail.com

L.M. KOZAK, DSc. (Biology), Senior Researcher, Leading Researcher of the Medical Information Systems Department, International Research and Training Center for Technologies and Systems of the NAS and MES of Ukraine, Glushkov ave., 40, Kyiv, 03187, Ukraine, lmkozak52@gmail.com

E.V. GORSHKOV, PhD (Medicine), Researcher of the Medical Information Systems Department, International Research and Training Center for Technologies and Systems of the NAS and MES of Ukraine, Glushkov ave., 40, Kyiv, 03187, Ukraine,

e.gorshkov@gmail.com

M. NAJAFIAN TUMAJANI, Junior Researcher of the Medical Information Systems Department, International Research and Training Center for Technologies and Systems of the NAS and MES of Ukraine, Glushkov ave., 40, Kyiv, 03187 , Ukraine,

najafian@mail.ru

T.A. MARESOVA, Junior Researcher of the Medical Information Systems Department, International Research and Training Center for Information Technologies and Systems of the NAS and MES of Ukraine, Glushkov ave., 40, Kyiv, 03187, Ukraine,

tamaresova@gmail.com

\title{
IYTEGRATION ENVIRONMENT SOFTWARE MODULE FOR ACCUMULATION AND EXCHANGE OF DIGITAL MEDICAL DATA
}

Introduction. The development of effective digital medicine tools is an intensive and complex process that requires the interdisciplinary efforts of a wide range of experts, from scientists and engineers to ethics experts and lawyers. Digital medicine products have great potential for improving medical measurement, diagnosis and treatment. One of the main challenges for the healthcare sector is to address the issue of fast, convenient and secure exchange of information about patients' health. Service-oriented architectures of such products may accomplish many of the challenges facing healthcare systems.

The purpose of the paper is to develop an information and software module ExchangeDMD to ensure the accumulation, storage and exchange of diagnostic medical data in accordance with modern medical information standards to maintain the interoperability function as one of the leading principles of digital medicine.

Results. A special adaptive architecture of digital medicine infrastructure has been developed, which enables an integrated solution of data exchange between participants of providing medical services, which is carried out with the help of web services. The specifics of different types of medical information are analyzed and taken into account in accordance with the access regime for its processing. The module structure has been developed and implemented in software, which has three main levels: central virtual storage (virtual data center to implement certain functions), remote administration segment (technical support and administration network) and user segment (mobile devices and user-patient applications).

Conclusions. The ExchangeDMD information and software module is designed to ensure the accumulation of patient data, integration between the various units within the system, as well as to ensure the management of this data by health care personnel. The ExchangeDMD module is built using the international standard HL7CDA, which enable to formalize electronic medical records using RIM (information model links) to attract the necessary directories and classifiers when creating medical records and documents.

Keywords: digital medicine, service-oriented architecture, international standard HL7CDA, interoperability, electronic medical records. 


\section{Introduction}

The provision of medical care becomes a joint responsibility of different groups of medical professionals of medical institutions and institutions of different levels of medical services. Accordingly, one of the main challenges for the health sector is to address the issue of rapid, convenient and secure exchange of information about patients' health, including their medical records. As healthcare facilities (HFs) increasingly use information technology and information processing operations expand, the need for effective patient data sharing is becoming increasingly important.

Today, all data and medical information operations are directly dependent on the level of interoperability in healthcare, as interoperability is defined as the ability of different information systems, devices and applications to access, share, integrate and use data in a coordinated way to ensure timely and seamless information exchange and optimize the process of providing medical care.

According to the information presented in [1, 2], several levels of participants' interaction organization in the process of providing medical services are determined:

- at the first level, the requirements for interconnection required for one system or program for secure data transmission to another structure and obtaining data from it are set;

- at the second level, the format, syntax and organization of data exchange, in particular at the level of the data field for semantic interpretation is determined;

- the third level of the organization is aimed at providing common basic models and codification of data, including the use of data elements with standardized definitions from publicly available sets of values and coding dictionaries, which gives common understanding and meaning for the user;

- the fourth organizational level covers governance, policy, social, legal, and organizational considerations to facilitate secure, seamless, and timely communication and use of data both within and between organizations.

These components support shared consent, trust, and integrated end-user workflows in the digital medicine infrastructure.
Thus, the development and use of information technology for the accumulation, storage and exchange of medical data to ensure the rapid diagnosis and analysis of the dynamics of patient health in the digital medicine infrastructure is one of the most important ways to improve health care.

\section{Problem Statement}

Traditionally, health care has focused on health care providers, i.e. public and private medical institutions and organizations that provide medical diagnostic services. But now the WHO defines the focus of e-health systems on the patient as one of the global principles of digital medicine [3], and this principle, which focuses on the patient from the moment when the patient needs to seek medical help before he is cured, has been approved and applied to the digital medicine development $[4,5]$.

According to our definition [6], digital medicine covers a set of methods, technologies and technical means of computer support of medical and diagnostic process, the use of which dramatically increases the effectiveness of medical care for individuals patients and populations and populations. It is the use of modern information technology and software products of mobile medicine that can help solve these problems.

Patients need easy access to digital medical records, regardless of the environment in which these records are created and stored (low-tech - a typical information resource of the HFs, or hightech - the Internet, cloud technology, etc.).

Information and software of digital medicine infrastructure are developed based on the main functions implemented during the exchange of information and data between different participants in the health care process, as taken into account in our information model of medical data exchange in digital medicine infrastructure. According to international experience, such an infrastructure consists of several participants who, firstly, provide medical or advisory care, and secondly, are patients who can generate medical data and information using any source - diagnostic devices, electronic medical records and documents, etc. [7]. From the point of view of designing such systems, their architec- 
ture should cover all elements of the organization, such as business, programs, data, infrastructure. The proposed adaptive integrated architecture should be consistent with the IT strategy, involving cloud and mobile IT. Such a framework of adaptive architecture has been specifically designed to support digital transformation, taking into account the prospects for the E-Health development [8].

The digital healthcare infrastructure is based on compliance with the HL7 standard for the registration of health information services and their results, which meets the requirements of the service-oriented architecture (SOA) for the medical information exchange. Note that in order to improve health care services, it is necessary to have technically sound compatibility standards, taking into account the common set of requirements for access to information systems of all health care facilities (HCFs). Various methods, standards and languages have been proposed for the medical information exchange between HCFs. Thus, EJB, XML and RDF are used to exchange textual information from electronic medical records. The DICOM (Digital Imaging and Medical Communications) standard makes it easy to integrate established health information systems, but this standard may provide limited terminological control.

To unify these processes, international standards are used, including the third version of the HL7 standard - CDA (Clinical Documentation Architecture), which supports the interoperability resource in health care, developed by HL7 International $[9,10]$. CDA is designed to address the complexity of medical Data, it uses the Internet to connect various discrete elements.

Based on the principle of interoperability, the functionality of systems or software modules for registration, storage and exchange of medical information is based on the following tasks:

- creating of a single information space within the infrastructure of digital medicine;

- improving the efficiency of the accumulated data use on diagnostic and therapeutic processes;

- creating of a tool for data exchange with other information systems used in the medical space of Ukraine.
- The purpose of this paper is to develop an information and software module Exchange DMD for provision the accumulation, storage and exchange of diagnostic medical data, taking into account modern medical information standards to maintain interoperability as one of the leading principles of digital medicine.

\section{ExchangeDMD Software}

At present, Ukraine is implementing the electronic health care system (EHS), which is an information and telecommunication system with the functions of automation of medical services accounting and management of medical information in electronic form [11]. The technical component of the EHS architecture is based on a hybrid two-component model system with a combination of a central database (CBD) of state subordination and many electronic medical information systems in health care facilities. Integration of software modules and systems for diagnosing specific pathologies and organization of effective exchange of received and stored medical information is the next step in the development of EHS.

The general scheme of information flows in the application of the ExchangeDMD module in E-Health of Ukraine is shown in Fig. 1.

The general structure of the information module as an information and telecommunication system consists of three main levels:

- central virtual storage (virtual data center, which provides the implementation of certain functions);

- remote administration segment (technical support and administration network);

user segment (mobile devices and patient-user applications).

The central virtual repository includes the following servers or provides the following service functions:

- web server - provides work through the web portal and access to data through any web browser;

- application server - ensures the implementation of the logic of work;

- database server - contains information about users and logs their actions; 


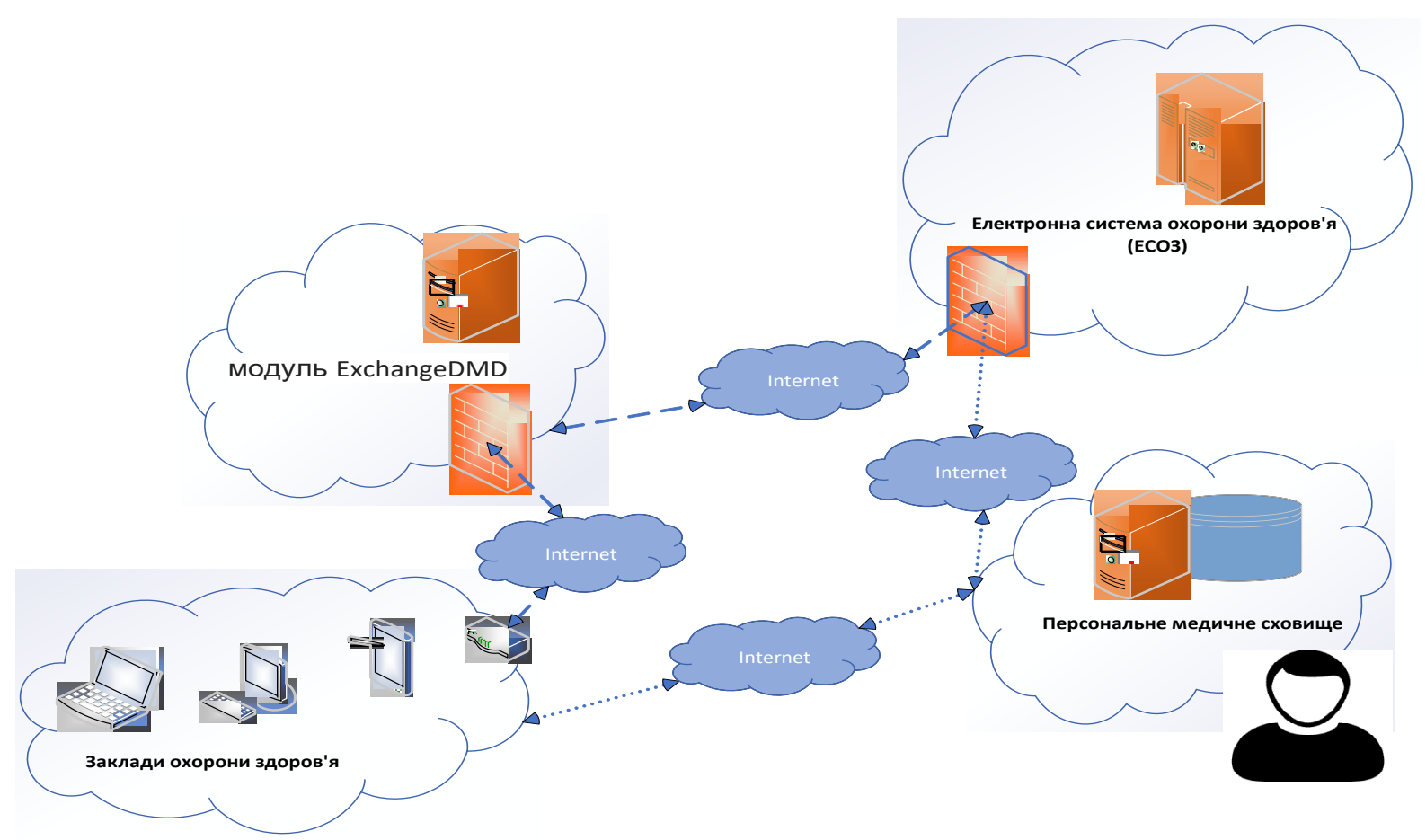

Fig. 1. Scheme of information flows in the application of the ExchangeDMD module in E-Health of Ukraine

- management server (connection security server) - provides a secure channel in an unsecured environment, such as between the central virtual storage and the remote administration segment, between the user and the database.

When working with the central database of EHR, it is necessary to take into account the availability of a qualifying expert signature service, which can be implemented within the application server.

Network equipment must ensure the interaction of servers, remote administration segment and user access segment, perform the basic function of counteracting network attacks from the Internet (including the function of filtering network traffic).

The remote administration segment includes administrators' workstations to ensure the work of staff.

The above servers can operate both on physical servers (each server with certain functions runs on a separate physical server) and in a virtual environment running a virtualization system (on a physical server/server cluster creates a virtual environment in which, in turn, create appropriate virtual servers). In the case of building a system in a virtual environment, servers for creating and managing a virtual environment or separate management mechanisms must be provided.

\section{Classification of the System Infor- mation Resources by Access Mode}

The processed information is divided into the following categories according to the requirements for its protection:

- open information;

- confidential information about the person (hereinafter - personal data);

- medical information;

- medical information indicating the patient's personal data;

- technological information.

Open information includes: register of administrative units, impersonal information, document templates and other open information that is processed in the system. 


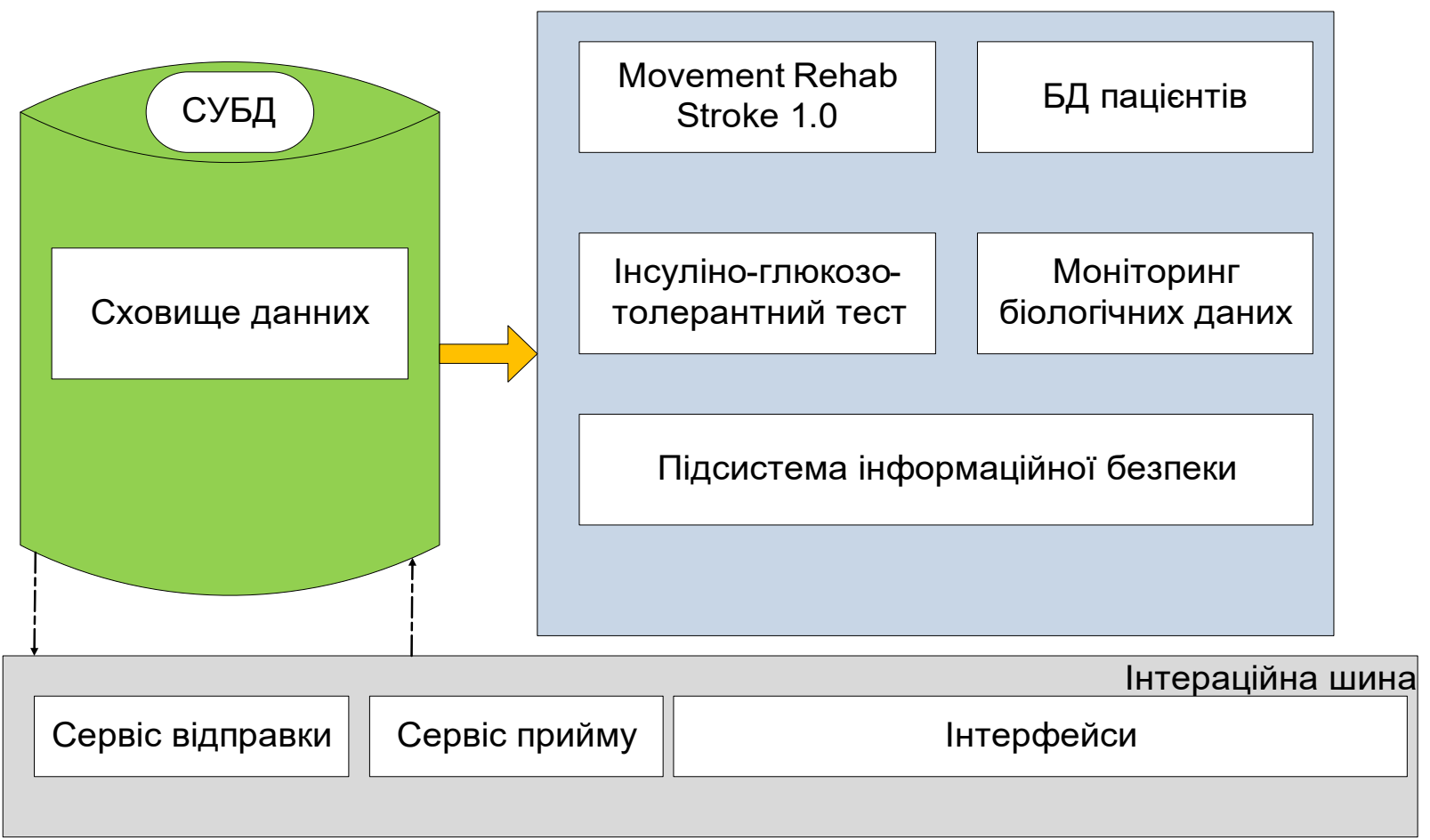

Fig. 2. ExchangeDMD software module architecture

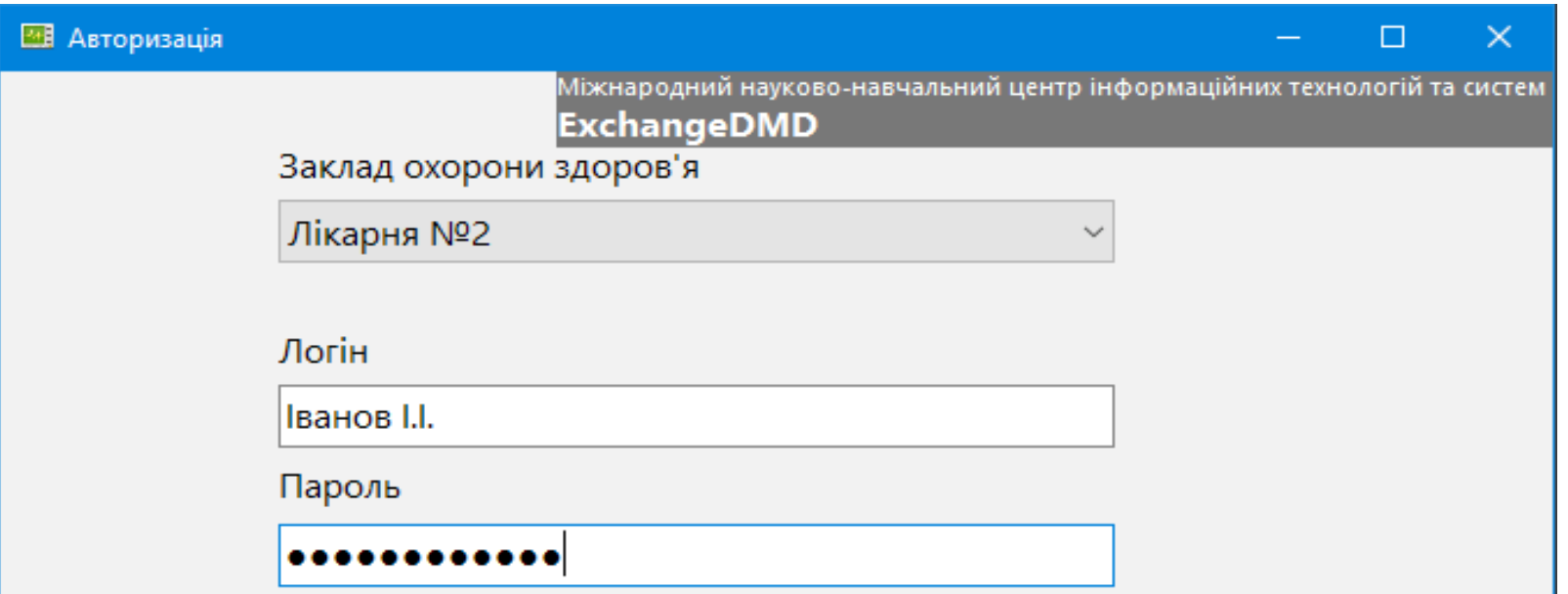

Fig. 3. Doctor'authorization to enter the software module

Depending on the processing location, open information is presented as information objects at the network, channel and physical levels of the Open Systems Interaction (OSI) model (respectively, in 
평 Щоденник

Міжнародний науково-навчальний центр інформаційних технологій та систем

ExchangeDMD

Вага тіла АT/ЧСС Температура SPO2

Дата

18.11.2021

AT

Значення

$150 / 80$

$4 \mathrm{ac}$

09:50:22

чCC

Ліва рука Права рука

$65 \quad 70$

Fig. 4. "Diary" electronic medical document with information about the patient's health - Blood pressure

Фан Щонник

$\square \times$

Міжнародний науково-навчальний центр інформаційних технологій та систем

ExchangeDMD

Вага тіла АT/ЧСC Температура SPO2

\begin{tabular}{ll} 
Дата & Час \\
\hline 18.11 .2021 & $\square \div$ \\
\hline
\end{tabular}

Значення

98

Fig. 5. "Diary" electronic medical document with information about the patient's health - Data on blood oxygen levels

the form of IP packets, network frames and physical signals).
This information is in the form of publicly available web page information for Frontend users. The

ISSN 2706-8145, Control systems and computers, 2021, № 5-6 
四 Інсуліно-Глюкозо-Толерантний тест

\section{Сніданок}

Концентрація глюкозу у крові

4 ммоль/л

доза введеного інсуліну рівень цукру в крові через 30 хв.

7

рівень цукру в крові через 60 хв.

7,1

Fig. 6. Screen form for data entry from insulin-glucose to-lerance test

\section{Кисть}

Ліва

Протиставлення великого пальця

Згинання пальців у кулак

Основна функція кисті

Розгинання пальців кисті

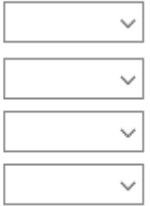

Права

Протиставлення великого пальця

Згинання пальців у кулак

Основна функція кисті

Розгинання пальців кисті

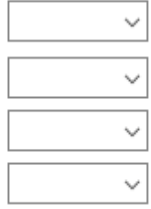

36 ерегти

Fig. 7. Screen form for entering the brush status

information in this category is subject to increased requirements for maintaining integrity and ensuring its accessibility.
Confidential information is information about personal data of individuals (users) and their access attributes. Confidential information (personal 


\section{Кульшовий суглоб}

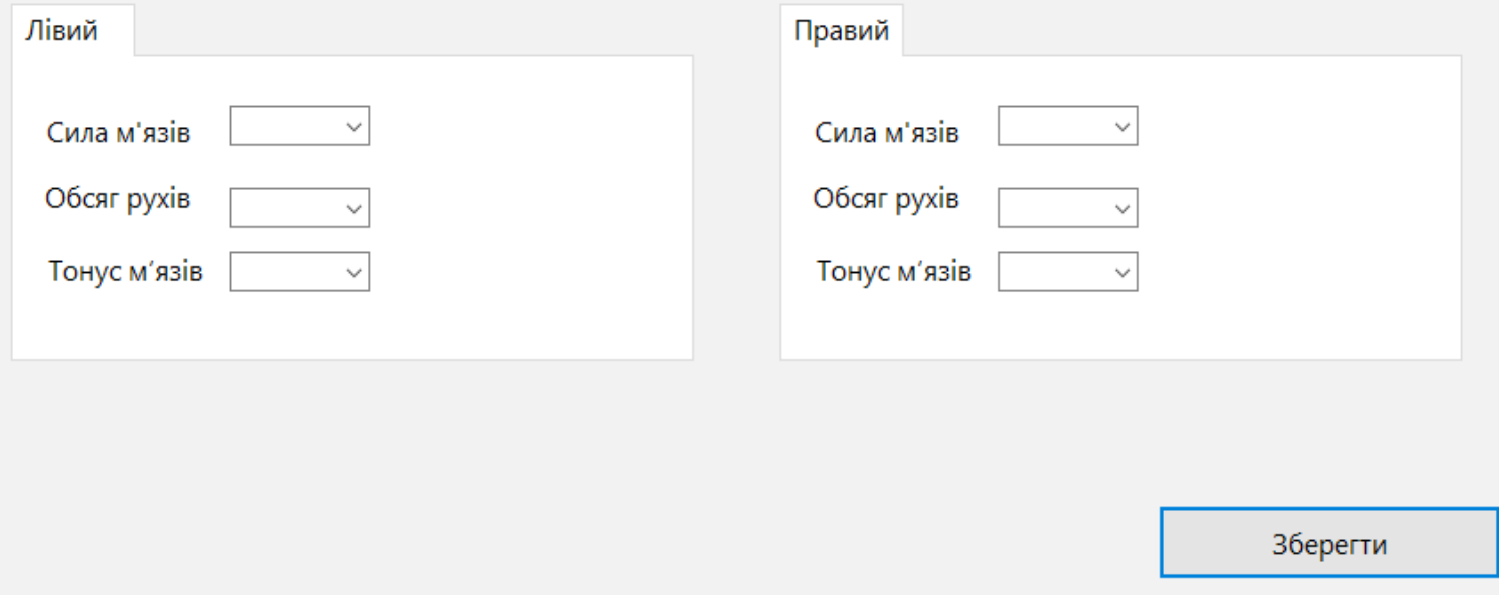

Fig. 8. Screen form of input of data on a condition of a hip joint

data) includes such information about the patient: surname, name, patronymic; contact phone; place of residence: index, region, district, settlement, street, house, apartment, etc. The confidential information processing is carried out only by responsible persons in accordance with their functional responsibilities.

Depending on the place of its processing, confidential information is stored in:

- disk files and responsible persons workstations in accordance with their functional responsibilities;

- information objects of network, channel and physical levels (in the form of IP packets, network frames and physical signals).

Emphasize once again, this information is subject to increased requirements for ensuring confidentiality, integrity and accessibility.

Medical information (without specifying the patient's personal data) contains information about the fact of seeking medical help, the patient's health; diagnosis (name) of his disease, means and methods of treatment, possible prognosis of the disease and other information obtained during the examination and treatment of the patient.

This information is subject to protection to maintain its integrity and accessibility.

Medical information indicating the patient's personal data is formed at the stage of aggregation of medical information and personal data of the patient to whom it belongs. According to its legal status, this information is confidential.

Technological information (TI) consists of data on the administration and management of information systems. TI is intended for use only by authorized users-administrators. This information is subject to protection in terms of maintaining confidentiality, integrity and ensuring its accessibility, as it is responsible for the manageability of the system.

The technological information includes the following content:

- configuration and system objects, which, respectively, determine the configuration parameters of the equipment and specific data used by the equipment in the process of its operation; 
- information objects that contain access attributes of users and administrators to determine their authorization in the system (personal identifiers and passwords);

- information objects that contain data on the operation of software and hardware (configuration settings);

- settings of the operating system, databases, rules of access delimitation;

- setting and configuration of network and communication equipment;

- setting antivirus protection for servers, workstations;

- information objects with reporting data on the functioning of the software and hardware complex and user actions (logs, log files):

- event logs and settings for logging events, audit $\log$ information, etc.

According to the nature of the information, the modes of access to it are distributed in the developed module for each participant in the process of providing medical care.

\section{Architecture and Information Characteristics of ExchangeDMD Software Module}

The main tasks of the ExchangeDMD information and software module are the patient data collection, integration between different blocks within the module (including blocks of diagnostic data of the nervous and endocrine systems), as well as ensuring the work of health care staff, data management and data exchange central database of the electronic health care system. This module can be used to improve the communication of health professionals with patients and to optimize patient access to a wide range of medical data located in different HCFs, software or mobile devices. The module is based on the developed algorithms for the accumulation of personal medical data [12]. The architecture of the ExchangeDMD software module is given in Fig. 2.

The proposed information and software module "ExchangeDMD" is built using the international standard HL7 CDA on the basis of electronic medical document, which structurally corresponds to the registration form F.003.o "Medical card of an inpatient".

The doctor who uses this module, first, must register by selecting his data from the directory of medical staff of the clinic, and then gain access to the database (Fig. 3).

If the patient data is in the database of patients, the doctor selects them from the list, in the absence of these data, the doctor enters them into the system. The doctor starts work from a page that reflects the medical and demographic patient's data, i.e. his last name, first name and patronymic, information about his gender, place of residence, work. Then the diagnosis and other necessary data are entered. Then the doctor goes to the "Diary" with available data on the main physiological parameters of the patient - blood pressure, body temperature, oxygen level, etc. (examples of screen forms are shown in Fig. 4 and 5).

A reference to the "Diary" is necessary in order to record the patient physiological background. These actions precede the work directly with the entering indicators for the studied physiological systems (in particular, the endocrine and nervous systems) for further analysis and diagnosis of the particular patient condition. The doctor chooses in which direction he will work with the patient. For example, Figure 6 shows the screen for entering data on insulin-glucose tolerance test, Fig. 7 for entering the status of different segments of the musculoskeletal system.

Insulin-glucose tolerance test is a method of assessing the condition of a patient with diabetes mellitus and his sensitivity to injectable insulin. The main indicators, as shown in Fig. 6, are blood glucose levels in $\mathrm{mmol} / \mathrm{l}$, the dose of insulin in relative units and data on blood glucose levels $30 \mathrm{~min}$ utes and 1 hour after insulin injection.

According to the research methodology, such indicators are determined three times a day: during breakfast, lunch and dinner. Fig. 6 shows the input of data obtained during breakfast. The same indicators are determined in the following meals and entered into the appropriate screen forms. The results of this test determine the patient's sensitivity 
to insulin and provide a predicted dose of insulin before the next meal.

If the doctor needs to work in another direction, he chooses a study to assess the degree of impaired motor function of the patient due to stroke. According to this study, data on the state of the muscular system - different parts of the extremities of a person after a stroke.

The evaluation results are based on three indicators: muscle strength, muscle tone, and range of motion. The interface is designed in such a way that it is convenient and easier for the doctor to enter data on an expert scale. Examples of such an interface are given in Fig. 7, 8.

Saving data in the software module. The data warehouse of the software module provides storage of all necessary information for accounting and data analysis, as well as information necessary to differentiate user access rights to data and functions of the module. Data storage in the software module is based on modern object-relational databases that provide logical and physical integrity of data.

The data warehouse ensures compliance with the following general requirements:

- the use of agreed formats of data presentation, which eliminates duplication and input of redundant information;

- maintaining the completeness of information to achieve the goal of system creating;
- delimitation of access to data depending on the type of information and user rights of the software module.

During the development of the database, specifications were formed, which take into account the name of each indicator, mask and type: text (string), date, number (integer), number (float).

Thus, the developed information and software module ExchangeDMD can be used for a specific purpose - to ensure the accumulation of digital medical data and enable the exchange of this data between different clinical institutions.

\section{Conclusions}

The ExchangeDMD information and software module is designed to ensure the accumulation of patient data, integration between different units within the system, as well as to ensure the management of this data by health care personnel. The ExchangeDMD module is built using the international HL7 standard CDA.

To enable the safe exchange of medical data, the specifics of different types of medical information are analyzed and taken into account in accordance with the mode of access for its processing by various participants in the process of providing medical care.

\section{REFERENCES}

1. Luna, D., Campos, F., Otero, C., 2019. Interoperability in Digital Reference material. IDB. 52 p.

2. Walker, J., Pan, E., Johnston, D., Adler-Milstein, J., Bates, D. W., y Middleton, B. The Value Of Health Care Information Exchange and Interoperability. [online] Available at: $<$ https://www.researchgate.net/publication/8072860 $>$ [Accessed 14 May 2021].

3. Draft global strategy on digital health 2020-2025. July 2020 by WHO. [online] Available at: <https://www.who.int/ docs/default-source/documents/gs4dhdaa2a9f352b0445bafbc79ca799dce4d.pdf > [Accessed 14 May 2021].

4. Zakka, Je. The WHO Global Strategy on Digital Health: What You Need to Know. [online] Available at: <https://blog. xclinical.com/the-who-global-strategy-on-digital-health-what-you-need-to-know\#: :text=In\%20April\%202019\%20 The\%20World,adoption\%20of\%20appropriate\%20digital\%20health\%E2\%80\%9D> [Accessed 5 Jul. 2021].

5. Reddy, M. Digital Transformation in Healthcare in 2021: 7 Key Trends. [online] Available at: <https://www.digitalauthority.me/resources/state-of-digital-transformation-healthcare/> [Accessed 14 Oct. 2021].

6. Kozak, L.M., Kovalenko, A.S., Kryvova, O.A., Romanyuk, O.A., 2018. "Digital Transformation in Medicine: From Formalized Medical Documents to Information Technologies of Digital Medicine”. Kibernetika i vy islitel'na tehnika. 4 (194), pp. 61-78. https://doi.org/10.15407/kvt194.04.061 
7. Khan, F.Z., Soiland-Reyes, S., Sinnott, R.O., Lonie, A., Goble, C., Crusoe, M.R., 2019. "Crusoe Sharing interoperable workflow provenance: A review of best practices and their practical application in CWL Prov". Giga Science, N8, pp. 1-27. https://doi.org/10.1093/gigascience/giz095

8. Masuda, Yo., Zimmermann, A, Viswanathan, M., Bass, M., Nakamura, O., Yamamo, Sh. Adaptive Enterprise Architecture for the Digital Healthcare Industry: A Digital Platform for Drug Development. [online]. Available at: <https:// keio.pure.elsevier.com/en/publications/adaptive-enterprise-architecture-for-the-digital-healthcare-indus $>$ [Accessed 11 Aug. 2020].

9. Welcome to FHIR. [online]. Available at: <https://www.hl7.org/fhir/> [Accessed 11 Sept. 2020].

10. Kovalenko, O.S., Mishchenko, R.F., Kozak, L.M., 2019. "Transformation of Clinical Decision Support Systemsin to FHIR Structures to Ensure Quality of Medical Care”. Cybernetics and computer engineering, 4 (198), pp. 78-94. https://doi.org/10.15407/kvt198.04.078

11. On approval of the Concept of development of the digital economy and society of Ukraine for 2018-2020 and approval of the action plan for its implementation. [online]. Available at: $<$ https://zakon.rada.gov.ua/laws/show/67-2018\%D1\%80\#Text> [Accessed 12 Nov. 2020] (In Ukrainian) [Про схвалення Концепції розвитку цифрової економіки та суспільства України на 2018-2020 роки та затвердження плану заходів щодо іiї реалізації. https://zakon.rada. gov.ua/laws/show/67-2018-\%D1\%80\#Text].

12. Romaniuk, O.O., Kozak, L.M., and Kovalenko, O.S., 2021. "Formation of Interoperable Digital Medicine Information Environment: Personal Medical Data". Sci. innov., 17, no. 5, pp. 50-62.

Received 30.11.2021 
O.C. Коваленко, доктор мед. наук, проф., Міжнародний науково-навчальний центр

інформаційних технологій та систем НАН та МОН України,

03187, м. Київ, просп. Академіка Глушкова, 40,

askov49@gmail.com,

Л.М. Козак, доктор біол. наук, с.н.с., пров. н.с., Міжнародний науково-навчальний центр

інформаційних технологій та систем НАН та МОН України,

03187, м. Київ, просп. Академіка Глушкова, 40,

lmkozak52@gmail.com,

Є.B. Горшков, наук. співробітник, Міжнародний науково-навчальний центр інформаційних

технологій та систем НАН та МОН України,

03187, м. Київ, просп. Академіка Глушкова, 40,

e.gorshkov@gmail.com,

M. Наджифіан Туманджані, молодший наук. співробітник, Міжнародний науково-навчальний центр

інформаційних технологій та систем НАН та МОН України,

03187, м. Київ, просп. Академіка Глушкова, 40,

najafian@mail.ru

T.A. Маресова, молодший наук. співробітник, Міжнародний науково-навчальний центр

інформаційних технологій та систем НАН та МОН України,

03187, м. Київ, просп. Академіка Глушкова, 40,

tamaresova@gmail.com

\section{ПРОГРАМНИЙ МОДУЛЬ ІНТЕГРУВАЛЬНОГО СЕРЕДОВИЩА ДЛЯ АКУМУЛЮВАННЯ І ОБМІНЮВАННЯ ЦИФРОВИМИ МЕДИЧНИМИ ДАНИМИ}

Вступ. Розроблення ефективних інструментів цифрової медицини - інтенсивний і складний процес, який вимагає міждисциплінарних зусиль широкого кола експертів, від науковців та інженерів до експертів з етики та юристів. Продукти цифрової медицини мають великі перспективи для поліпшення медичних вимірювань, діагностики та лікування. Однією з головних проблем для сектора охорони здоров'я є вирішення проблеми швидкого, зручного безпечного обміну інформацією про стан здоров'я пацієнтів. Сервісно-орієнтовані архітектури таких продуктів вирішують багато проблем з якими стикаються системи охорони здоров'я.

Метою роботи $\epsilon$ розроблення інформаційно-програмного модуля ExchangeDMD для забезпечення акумулювання, зберігання та обміну діагностичними медичними даними з урахуванням сучасних медичних інформаційних стандартів для підтримки функції інтероперабельності як одного з провідних принципів цифрової медицини.

Результати. Розроблено спеціальну адаптивну архітектуру інфраструктури цифрової медицини, яка дає можливість інтеграційного вирішення обміну даними між учасниками цього процесу, що здійснюється за допомоги веб-сервісів. Проаналізовано та враховано специфіку різних типів медичної інформації відповідно до режиму доступу для ії опрацювання. Розроблено та програмно реалізовано структуру модуля, яка має три основних рівня: центральне віртуальне сховище (віртуальний датацентр для забезпечення реалізації визначених функцій), сегмент віддаленого адміністрування (мережа забезпечення технічної підтримки та адміністрування) та сегмент користувачів (мобільні пристрої та застосунки користувача-пацієнта).

Висновки. Інформаційно-програмний модуль ExchangeDMD призначено для забезпечення накопичення даних про пацієнта, інтеграції між різними модулями всередині системи, а також для забезпечення керування цими даними персоналом закладів охорони здоров'я. Модуль ExchangeDMD побудовано із застосуванням міжнародного стандарту HL 7. CDA, що дає змогу формалізувати електронні медичні записи з використанням RIM (інформаційної моделі посилань) для залучення необхідних довідників та класифікаторів під час створення медичних записів і документів.

Ключові слова: иифрова медицина, сервісно-орієнтована архітектура, міжнародний стандарт HL7 CDA, інтероперабельність, електронні медичні записи. 